\title{
UTILIZAÇÃO DE ENXERTOS ÓSSEOS AUTÓGENOS EM CIRURGIAE TRAUMATOLOGIA BUCO-MAXILO-FACIAIS
}

Rafael SANTOS; Ricardo PASQUINI FILHO; Delson João da COSTA; Paulo Roberto MÜLLER; Nelson Luis Barbosa REBELLATO

A falta de osso nos rebordos alveolares tem sido um grande problema na recuperação estético-funcional em pacientes que tenham sofrido traumatismos dentoalveolares, extrações dentárias traumáticas, ausências dentárias congênita, patologias que envolvam os maxilares, além de infecções, sendo esta falta de osso uma das limitações para a reabilitação com implantes, por apresentar um volume ósseo inadequado para a estabilidade inicial. Os enxertos ósseos autógenos são geralmente indicados em combinação com implantes para restauração desses pacientes. Além disso, os pacientes com reabsorção moderada e objetivos protéticos ideais também podem exigir um aumento ósseo. Segundo MISCH (2000), o objetivo habitual dos enxertos ósseos autógenos é fornecer osso disponível suficiente para permitir a inserção dos implantes endósseos nos maxilares comprometidos, ou sanar as necessidades e os desejos estéticos e/ou protético do paciente com reabsorção moderada. Os enxertos autógenos permitem a inserção do implante endósseo com maior área de superfície, altura, quantidade e localização melhor, sendo obtido de sítios doadores diferentes do próprio corpo e de diferentes formas. 